\title{
Keefektifan Lama Perendaman Benih dengan Indole Acetic Acid terhadap Pertumbuhan Bibit Cabai Merah (Capsicum annuum L.)
}

\author{
Muhammad Alqamari*, Abdul Rahman Cemda, dan Muhtar Yusuf \\ Program Studi Agroekoteknologi, Fakultas Pertanian, \\ Universitas Muhammadiyah Sumatera Utara \\ Medan, Indonesia 20238 \\ *Email korespondensi: alqamari@umsu.ac.id
}

\begin{tabular}{|c|c|}
\hline INFO ARTIKEL & ABSTRACT/ABSTRAK \\
\hline Diterima: $\quad 10-05-2021$ & \\
\hline Direvisi: $\quad 26-06-2021$ & The Effectiveness of Soaking Duration with Indole Acetic Acid on the \\
\hline Dipublikasi: 11-08-2021 & Seedling Growth of Chili Pepper (Capsicum annuum L.) \\
\hline
\end{tabular}

Keywords: chili pepper, germination, indole acetic acid, soaking duration

Kata Kunci: cabai merah, daya kecambah, indole acetic acid, lama perendaman
The use of auxin growth regulators such as Indole Acetic Acid (IAA) has the potential to support improvement of seedlings in chili pepper. The study was aimed to determine the effectiveness of soaking the seeds of chili pepper (Capsicum annuum L.) local varieties of North Sumatra by using IAA on the seedlings growth. The study was conducted in the laboratory and experimental field, Faculty of Agriculture, University of Muhammadiyah Sumatera Utara from March to May 2020. The experimental method used was Completely Randomized Design (CRD) in non-factorial, the treatments were the soaking duration of IAA (L0 = untreated; L1 $=3$ hours; L2= 6 hours; L3= 9 hours; L4= 12 hours; L5= 15 hours; and L6= 18 hours) within three replications. The parameters observed were the percentage of germination, seedling height, number of leaves, fresh weight, and dry weight of seedlings. The data processed using ANOVA and followed by DMRT at the level of 5\% \pm standard error using SPSS statistics v.20 software. The results showed that the soaking duration of IAA could increase the percentage of germination, seedling height, number of leaves, fresh weight, and dry weight of chili pepper on local variety in North Sumatra. The highest increase was found in the soaking duration at 12 hours with the value of those parameters were $64.51 \%$; 49.04\%; 57.14\%; 117.50\%; dan 157.89\%, respectively. It gave better value compared to the untreated.

Penggunaan zat pengatur tumbuh auksin seperti Indole Acetic Acid (IAA) sangat potensial mendukung peningkatan perkecambahan benih cabai. Penelitian ini bertujuan untuk mengetahui keefektifan lama perendaman benih cabai merah (Capsicum annuum L.) varietas lokal Sumatera Utara dengan menggunakan IAA terhadap pertumbuhan bibitnya. Penelitian ini dilaksanakan di laboratorium dan kebun percobaan, Fakultas Pertanian, Universitas Muhammadiyah Sumatera Utara pada Maret-Mei 2020. Metode percobaan menggunakan Rancangan Acak Lengkap (RAL) non-faktorial yaitu lama perendaman benih dalam IAA (L0= 0 jam; $\mathrm{L} 1=3$ jam; $\mathrm{L} 2=6$ jam; $\mathrm{L} 3=9$ jam; L4= 12 jam; L5= 15 jam; dan L6= 18 jam) dengan 3 ulangan. Parameter yang diamati meliputi: persentase daya berkecambah, tinggi bibit, jumlah daun bibit, berat basah, dan berat kering bibit. Data diolah menggunakan sidik ragam dan dilanjutkan DMRT level 5\% \pm standart error dengan menggunakan software IBM SPSS statistics v.20. Hasil penelitian menunjukkan bahwa lama perendaman benih dalam IAA dapat 
meningkatkan persentase daya kecambah, tinggi bibit, jumlah daun, berat basah, dan berat kering bibit cabai merah varietas lokal Sumatera Utara. Peningkatan tertinggi terdapat pada lama perendaman benih 12 jam dengan nilai pada setiap parameter yang diamati tersebut di atas masing-masing sebesar $64,51 \% ; 49,04 \% ; 57,14 \% ; 117,50 \%$; dan $157,89 \%$. Nilai tersebut lebih baik dibandingkan kontrol.

\section{PENDAHULUAN}

Tanaman cabai merupakan salah satu komoditas hortikultura yang bernilai strategis dengan produksinya selama tahun 1980-2014 berfluktuasi cenderung meningkat. Produksi cabai didominasi di Jawa Barat sebesar 22,54\%, kemudian disusul Sumatera Utara sebesar 18,15\%, Jawa Tengah sebesar 14,71\%, Jawa Timur sebesar 9,66\%, Sumatera Barat sebesar 5,62\%, Aceh sebesar 4,42\%, dan Bengkulu sebesar 4,05\% (Kementerian Pertanian, 2015). Komoditas cabai ini berkontribusi sangat penting terhadap pendapatan keluarga petani. Namun, petani belum secara optimal melakukan inovasi teknologi dalam budidaya tanaman tersebut. Hal ini dikarenakan permasalahan teknis, sosial, dan modal yang digunakan (Dirjen Hotikultura, 2008). Salah satu problem petani dalam teknik budidaya tanaman cabai adalah petani masih akrab menggunakan benih lokal yang berasal dari turunan panen sebelumnya (Soetiarso dkk., 1999).

Penggunaan benih tanaman cabai merah varietas lokal memiliki kelemahan dibandingkan varietas unggul, seperti produktifitas yang lebih rendah, lebih peka terhadap serangan organisme pengganggu tanaman, dan rendahnya tingkat viabilitas benih. Setiawan dkk. (2012) melaporkan bahwa penggunaan varietas unggul (Lembang-1) memiliki hasil buah cabai merah sebesar 10,22 ton/ha dan lebih tinggi dibandingkan varietas lokal (Pakem) sebesar 7,37 ton/ha. Septiana \& Islami (2018) melaporkan bahwa tanaman cabai merah varietas unggul (Pilar, Jet Set, dan Trisula) tanpa pupuk organik dapat menghasilkan berat segar buah masing-masing sebesar 16,52; 17,03 dan 11,69 ton/ha. Soetiarso dkk. (2011) melaporkan bahwa tanaman cabai merah varietas lokal yang dominan digunakan petani (hot chili) relatif peka terhadap serangan trips (Thrips parvispinus), kutu daun (Myzus persicae), dan kutu kebul (Bemisia tabaci) dibandingkan varietas unggul (Tanjung-2). Meskipun demikian, benih cabai merah varietas lokal memiliki keunggulan dibandingkan varietas unggul seperti pertumbuhan tinggi tanaman, dan lebar kanopi lebih baik serta lebih menguntungkan secara ekonomis dengan memberikan tingkat pengembalian marjinal sebesar $165,76 \%$ dibandingkan varietas unggul (Tanjung-2).

Beberapa keunggulan bibit lokal menjadi alasan bagi petani untuk tetap menggunakan bibit tersebut. Namun, penggunaan benih yang berasal dari turunan panen sebelumnya dapat menurunkan kualitas benih. Maka diperlukan upaya alternatif untuk pengembangan potensi benih tanaman cabai merah varietas lokal untuk meningkatkan viabilitas benih seperti penggunaan Zat Pengatur Tumbuh (ZPT) berupa auksin. Telah dilaporkan Soelaiman \& Ernawati (2013) bahwa penambahan IAA konsentrasi $1 \mathrm{mg} / \mathrm{l}$ sangat baik untuk menginduksi akar cabai keriting secara in vitro. Gundala dkk. (2018) juga melaporkan bahwa penggunaan konsentrasi $2 \mathrm{~g} / \mathrm{l}$ auksin IAA secara signifikan meningkatkan potensi tumbuh maksimum, indeks vigor dan kecepatan tumbuh relatif, daya berkecambah dan keserempakan tumbuh benih cabai kadaluarsa.

Penggunaan ZPT auksin (IAA) sangat potensial mendukung peningkatan kualitas benih, namun diperlukan informasi tentang durasi atau lama perendaman benih dalam IAA. Peneliti sebelumnya telah melaporkan bahwa lama perendaman yang terlalu pendek menyebabkan terhambatnya aktivitas enzim dalam meningkatkan perkecambahan atau kekuatan benih (Saini et al., 2017) sedangkan lama perendaman yang terlalu lama mengakibatkan rentannya bibit kehilangan air (Harris, 1996). Dengan demikian dibutuhkan pengkajian kembali bagaimana respon perkecambahan bibit tanaman cabai merah varietas lokal yang berasal dari petani akibat pengaruh lama perendaman IAA. Penelitian ini bertujuan untuk mengetahui keefektifan lama perendaman benih cabai merah (Capsicum annuum L.) varietas lokal Sumatera Utara dengan menggunakan IAA terhadap pertumbuhan bibitnya. 


\section{BAHAN DAN METODE}

\section{Lokasi dan Rancangan Penelitian}

Penelitian ini dilaksanakan di laboratorium dan kebun percobaan, Fakultas Pertanian, Universitas Muhammadiyah Sumatera Utara, Medan dari Bulan Maret sampai Mei 2020. Rancangan penelitian ini menggunakan Rancangan Acak Lengkap (RAL) non-faktorial yaitu faktor lama perendaman benih dengan Indole Acetic Acid (IAA) yang terdiri dari $\mathrm{L} 0=0 \mathrm{jam} ; \mathrm{L} 1=3 \mathrm{jam} ; \mathrm{L} 2=6 \mathrm{jam}$; L3= 9 jam; L4= 12 jam; L5= 15 jam; dan L6= 18 jam. Perlakuan diulang sebanyak tiga ulangan.

\section{Sumber dan Persiapan Benih Lokal Tanaman Cabai} Benih lokal tanaman cabai merah yang digunakan adalah varietas CMK Lokal Medan Batang Kuning diperoleh dari petani di Kelurahan Gundaling I, Kecamatan Berastagi, Kabupaten Karo, Sumatera Utara yang sudah mempersiapkan biji cabai siap ditanam. Benih disortasi berdasarkan ukuran dan umur yang seragam kemudian dicuci dengan air dan diendapkan serta diambil benih yang tenggelam dan ditiriskan.

\section{Perendaman Benih Cabai dengan IAA}

Pembuatan larutan IAA dilakukan dengan menimbang $1 \mathrm{~g}$ IAA dan dilarutkan secara homogen ke dalam $100 \mathrm{ml}$ aquades pada beaker glass atau setara dengan konsentrasi $1 \%$. Setelah itu, benih cabai yang sudah ditiriskan kemudian direndam ke dalam IAA sesuai dengan masing-masing perlakuan lamanya perendaman. Sebanyak 30 benih cabai direndam pada setiap perlakuan.

\section{Persiapan Media Kecambah dan Pemeliharaan Kecambah}

Topsoil dibersihkan dari kotoran dengan menggunakan ayakan sebanyak satu kali ayak kemudian dicampur kompos dengan perbandingan 3:1. Media kecambah sebanyak 50 g dimasukkan ke steroform yang dibentuk bulat dengan diameter 20 $\mathrm{cm}$ dan tinggi $12 \mathrm{~cm}$. Benih yang sudah ditanam dipelihara dengan menyiram menggunakan handsprayer sebanyak 2 kali sehari.

\section{Pengamatan dan Analisis Data}

Pengamatan pada penelitian ini dilakukan pada akhir penelitian yaitu 15 Hari Setelah Tanam (HST) yang meliputi pengamatan terhadap persentase daya berkecambah, tinggi bibit dihitung dari pangkal akar, jumlah daun bibit, berat basah bibit, dan berat kering bibit. Persentase daya kecambah (DB) dilakukan menggunakan rumus (ISTA, 2010) (persamaan 1) dan persentase peningkatan tinggi bibit, jumlah daun, berat basah dan berat kering bibit dihitung menggunakan rumus pada persamaan 2-5:

$$
\mathrm{DB}=\frac{\text { Jumlah kecambah hidup }}{\text { Jumlah benih yang dikecambahkan }} \times 100 \%
$$

$\%$ Peningkatan tinggi bibit $=\frac{\text { Tinggi bibit perlakuan }- \text { tinggi bibit tanpa perlakuan }}{\text { Tinggi bibit tanpa perlakuan }} \times 100 \%$

$\%$ Peningkatan jumlah daun $=\frac{\text { Jumlah daun perlakuan }- \text { jumlah daun tanpa perlakuan }}{\text { Jumlah daun tanpa perlakuan }} \times 100 \%$

$\%$ Peningkatan berat basah $=\frac{\text { Berat basah perlakuan }- \text { berat basah tanp a perlakuan }}{\text { Berat basah tanp a perlakuan }} \times 100 \%$

$\%$ Peningkatan berat kering $=\frac{\text { Berat kering perlakuan }- \text { berat kering tanpa perlakuan }}{\text { Berat kering tanpa perlakuan }} \times 100 \%(5)$

Perhitungan berat basah bibit dilakukan dengan mencabut bibit tanaman cabai dan membersihkan akarnya dari tanah kemudian ditimbang. Setelah itu bibit dioven dengan suhu $60^{\circ} \mathrm{C}$ selama 48 jam untuk memperoleh berat kering konstan. Data yang diperoleh kemudian diolah menggunakan sidik ragam (ANOVA) dan apabila terdapat hasil yang signifikan dilakukan pengujian
DMRT level $5 \% \quad \pm$ standart error dengan menggunakan software IBM SPSS statistics v.20.

\section{HASIL DAN PEMBAHASAN}

Hasil Pengamatan Beberapa Parameter Pertumbuhan Tanaman Cabai yang Direndam dalam IAA Daya Berkecambah (\%) 
Hasil analisis ANOVA terhadap daya kecambah menunjukkan bahwa lama perendaman benih dalam IAA dengan signifikan mempengaruhi daya kecambah cabai merah varietas lokal Sumatera Utara (Gambar 1). Persentase daya kecambah tertinggi ditemukan pada lama perendaman 12 jam sebesar $85 \%$ dibandingkan lama perendaman lainnya. Terjadi peningkatan daya kecambah cabai merah varietas lokal Sumatera Utara seiring dengan peningkatan lama perendaman sampai 12 jam (L4) sebesar $64,51 \%$ dibandingkan kontrol (0 jam) kemudian mengalami penurunan sampai lama perendaman 18 jam (L6) (Tabel 1). Daya kecambah cabai lebih rendah pada periode tersebut dibandingkan dengan perendaman benih 12 jam.

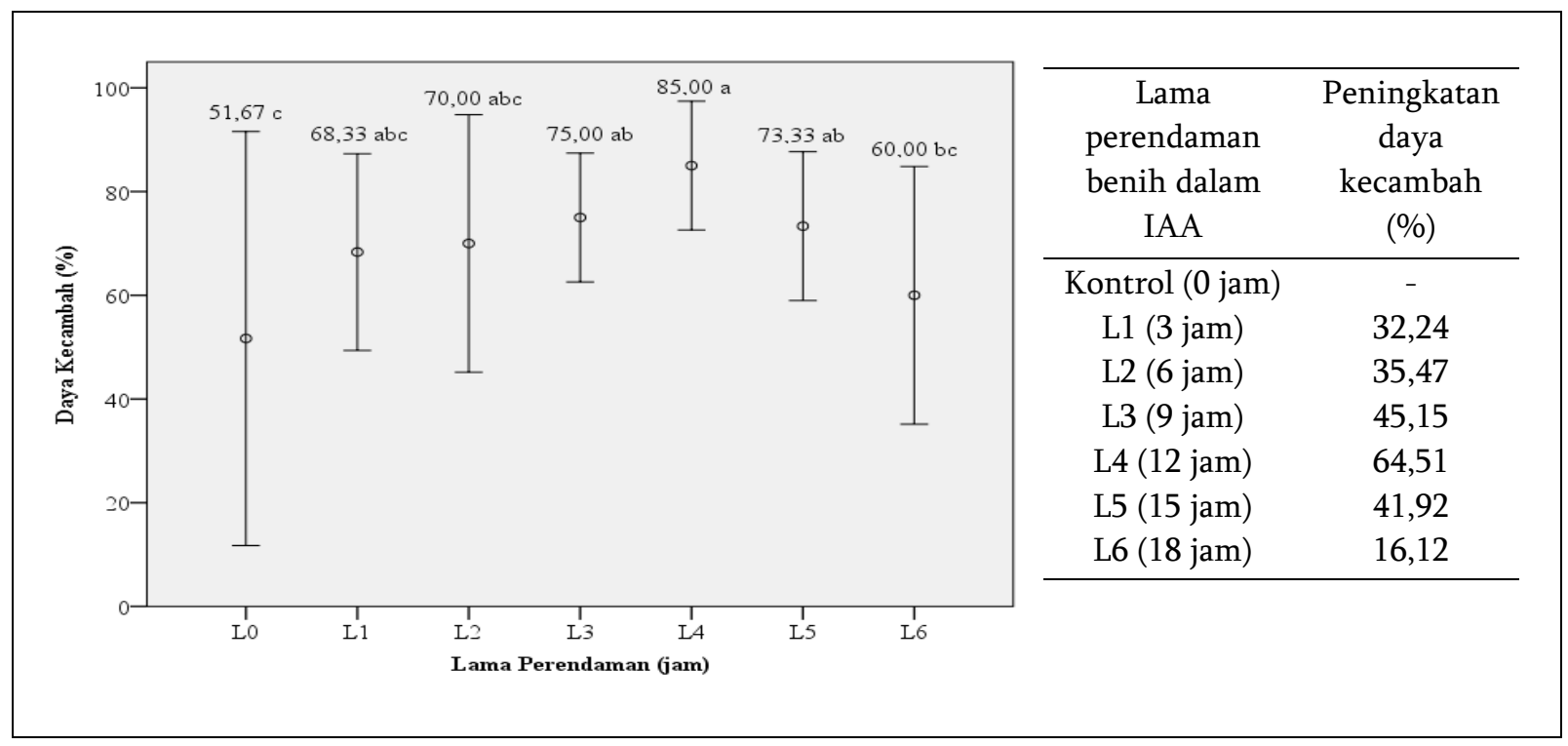

Gambar 1. Pengaruh lama perendaman benih pada IAA terhadap daya kecambah cabai merah varietas lokal Sumatera Utara dan persentase peningkatannya. Lama perendaman benih (L1=0 jam, L2= $3 \mathrm{jam}, \mathrm{L} 2=6 \mathrm{jam}$, $\mathrm{L} 3=9 \mathrm{jam}, \mathrm{L} 4=12 \mathrm{jam}, \mathrm{L} 5=15 \mathrm{jam}, \mathrm{L} 6=18 \mathrm{jam}$. Lingkaran kecil pada grafik menandakan rataan persentase daya kecambah dan garis vertikal menunjukkan standar error.

\section{Tinggi Bibit (cm)}

Hasil analisis ANOVA menunjukkan bahwa lama perendaman benih dalam IAA dengan signifikan dapat meningkatkan tinggi bibit cabai merah varietas lokal Sumatera Utara pada umur 15 HST (Gambar 2). Tinggi bibit cabai lokal tertinggi ditemukan pada lama perendaman 12 jam sebesar $11,67 \mathrm{~cm}$. Terjadi peningkatan tinggi bibit sebesar $36,27 \%$ dibandingkan dengan perlakuan kontrol. Gambar 2 menunjukkan bahwa terjadi peningkatan tinggi bibit cabai merah varietas lokal Sumatera Utara seiring dengan peningkatan lama perendaman sampai 12 jam (L4) sebesar 49,04\% dibandingkan lama perendaman 0 jam (L0) kemudian mengalami penurunan sampai lama perendaman 18 jam (L6).

\section{Jumlah Daun Bibit}

Dari data jumlah daun bibit yang dianalisis ANOVA diperoleh bahwa lama perendaman benih dalam IAA signifikan meningkatkan jumlah daun bibit cabai merah varietas lokal Sumatera Utara pada umur 15 HST (Gambar 3). Jumlah daun bibit cabai lokal tertinggi ditemukan pada lama perendaman 12 jam sebesar 11,00 helai dibandingkan lama perendaman lainnya. Gambar 3 menunjukkan bahwa terjadi peningkatan jumlah daun bibit cabai merah varietas lokal Sumatera Utara seiring dengan peningkatan lama perendaman sampai 12 jam (L4) sebesar $57,14 \%$ dibandingkan lama perendaman 0 jam (LO) kemudian jumlah daun bibit menurun ketika benih cabainya direndam lebih lama dari 12 jam (15 jam dan 18 jam). 


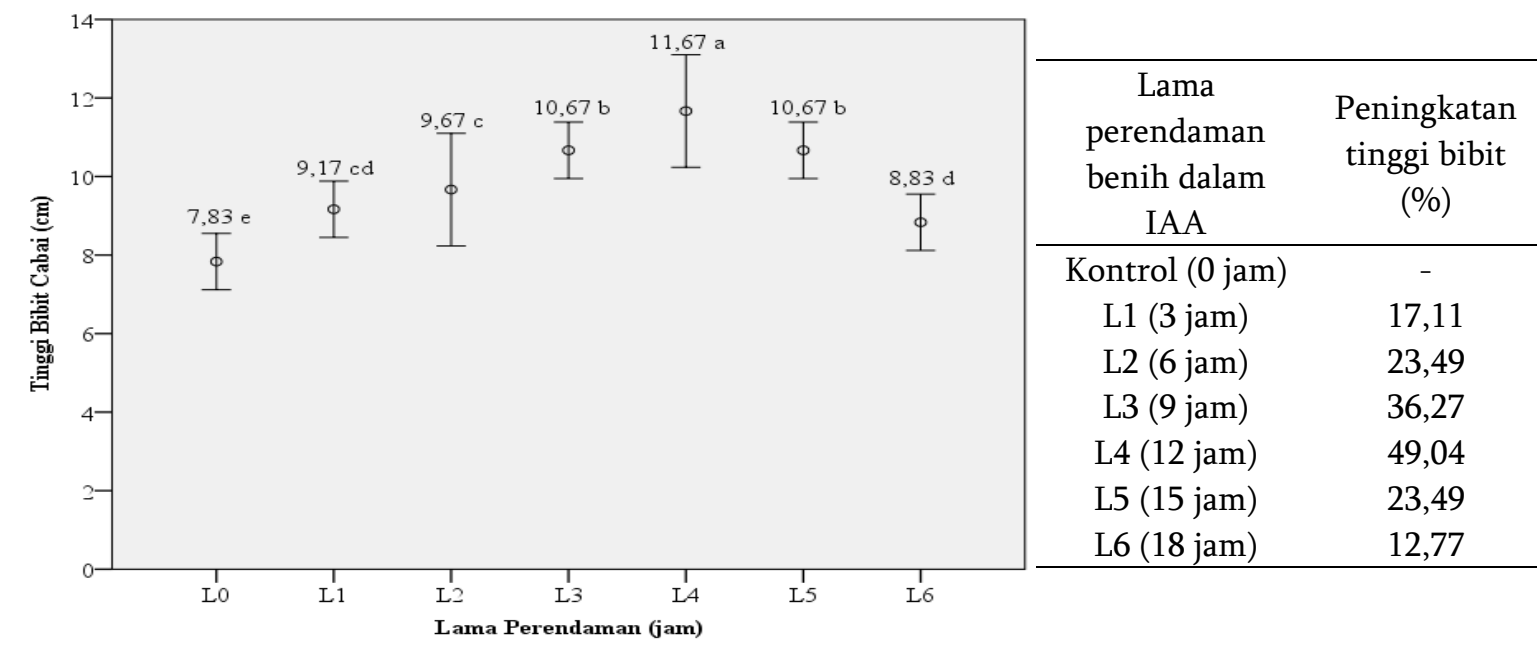

Gambar 2. Pengaruh lama perendaman benih dalam IAA terhadap tinggi bibit tanaman cabai merah varietas lokal Sumatera Utara dan persentase peningkatannya. Lama perendaman benih (L1=0 jam, L2= 3 jam, L2= 6 jam, L3= 9 jam, L4= 12 jam, L5= 15 jam, L6= 18 jam. Lingkaran kecil pada grafik menandakan rataan tinggi bibit dan garis vertikal menunjukkan standar error.

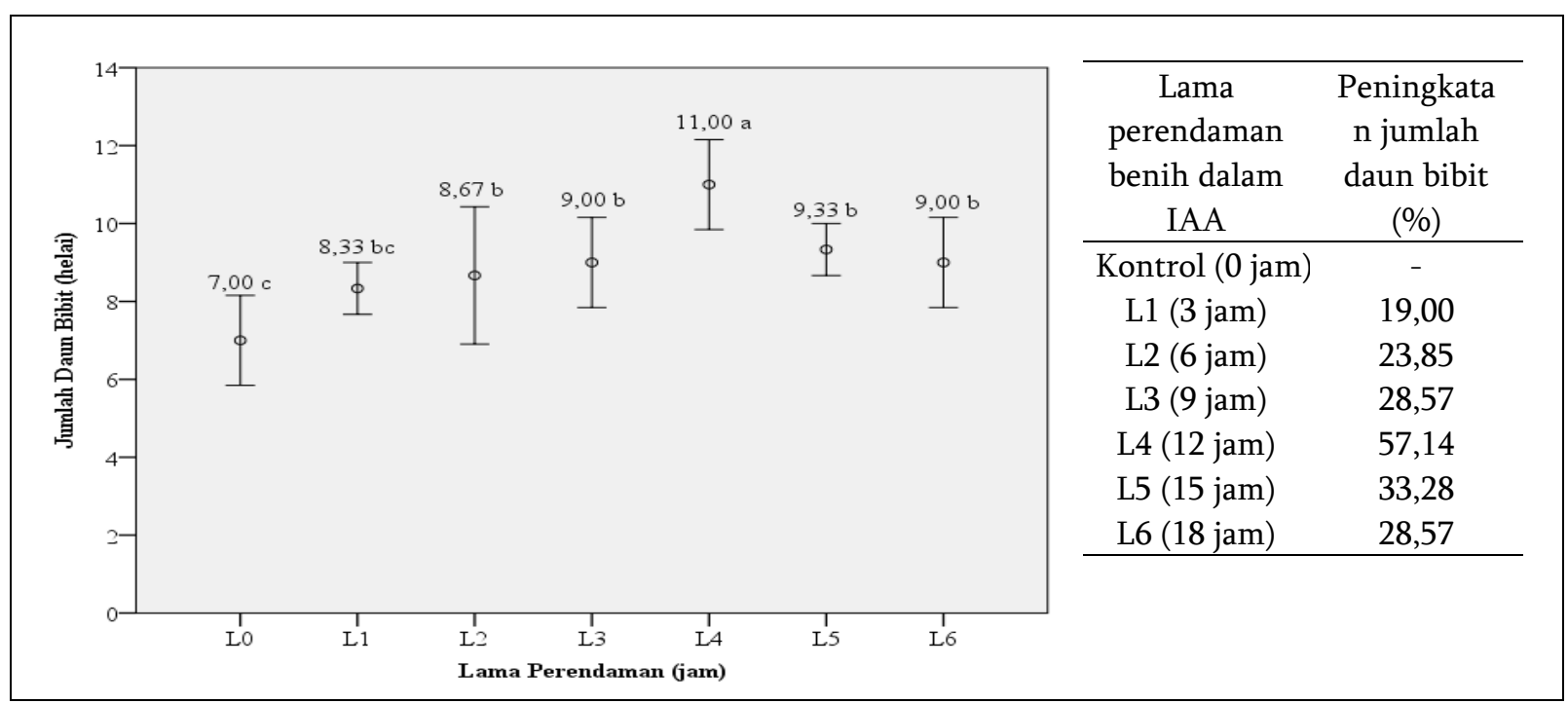

Gambar 3. Pengaruh lama perendaman benih dalam IAA terhadap jumlah daun bibit tanaman cabai merah varietas lokal Sumatera Utara dan persentase peningkatan jumlah daunnya. Lama perendaman benih (L1=0 jam, L2= 3 jam, L2= 6 jam, L3=9 jam, L4= 12 jam, L5= 15 jam, L6= 18 jam. Lingkaran kecil pada grafik menandakan rataan jumlah daun dan garis vertikal menunjukkan standar error.

\section{Berat Basah Bibit}

Berdasarkan hasil analisis ANOVA diperoleh lama perendaman benih dalam ZPT IAA signifikan meningkatkan berat basah bibit cabai merah varietas lokal Sumatera Utara (Gambar 4). Berat basah bibit cabai lokal tertinggi ditemukan pada lama perendaman 12 jam sebesar 3,48 g dibandingkan lama perendaman lainnya. Terjadi peningkatan berat basah bibit cabai merah varietas lokal Sumatera Utara pada semua perlakuan lama perendaman dibandingkan kontrol. Peningkatan berat basah bibit cabai merah tertinggi (117,50\%) terdapat pada perlakuan lama perendaman 12 jam (L4). 


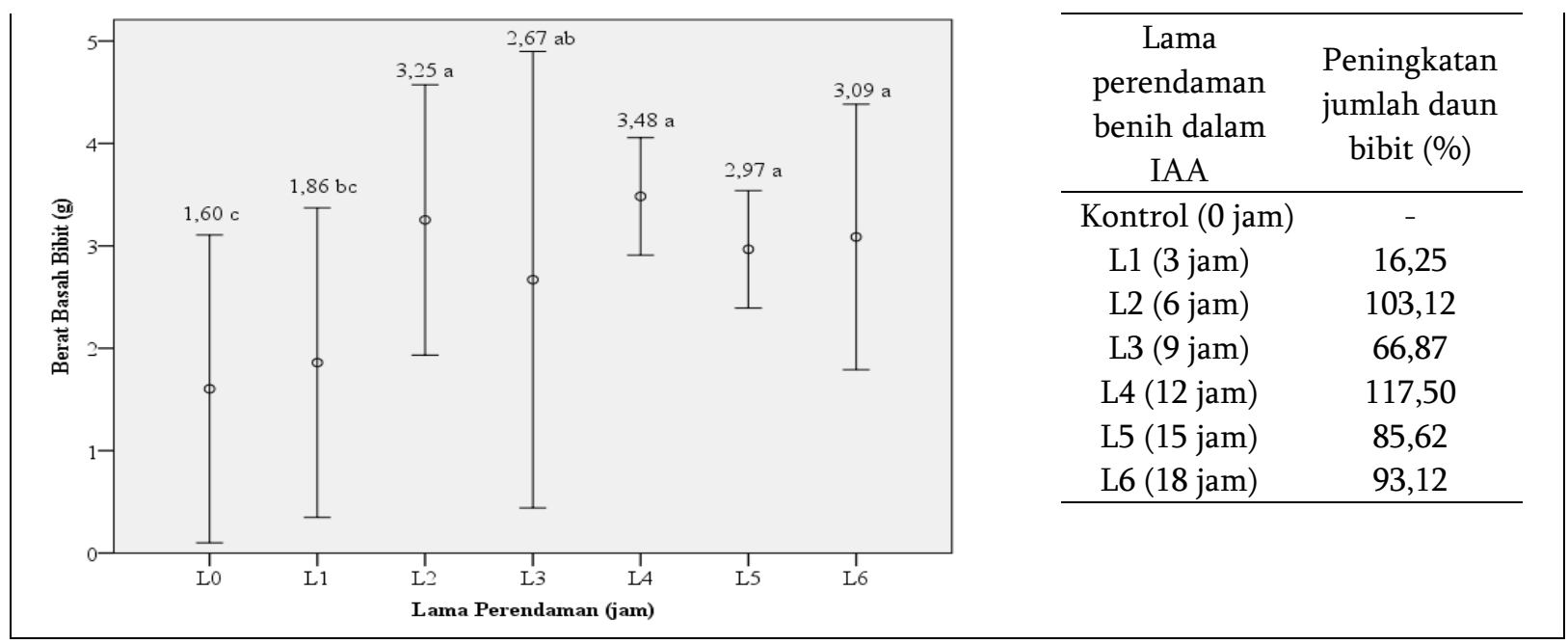

Gambar 4. Pengaruh lama perendaman benih dalam IAA terhadap berat basah bibit tanaman cabai merah varietas lokal Sumatera Utara. Lama perendaman benih (L1=0 jam, L2= 3 jam, L2= 6 jam, L3= 9 jam, L4= 12 jam, L5= 15 jam, L6= 18 jam. Lingkaran kecil pada grafik menandakan rataan berat basah bibit dan garis vertikal menunjukkan standar error.

\section{Berat Kering Bibit}

Berdasarkan hasil analisis ANOVA diperoleh lama perendaman benih dalam ZPT IAA signifikan meningkatkan berat kering bibit cabai merah varietas lokal Sumatera Utara (Gambar 5). Berat kering bibit cabai lokal tertinggi ditemukan pada lama perendaman 12 jam sebesar 0,49 g dibandingkan lama perendaman lainnya. Gambar 5 menunjukkan bahwa terjadi peningkatan berat kering bibit cabai merah varietas lokal Sumatera Utara pada semua perlakuan lama perendaman dibandingkan kontrol. Peningkatan berat kering bibit cabai merah tertinggi (157,89\%) terdapat pada perlakuan lama perendaman 12 jam (L4).

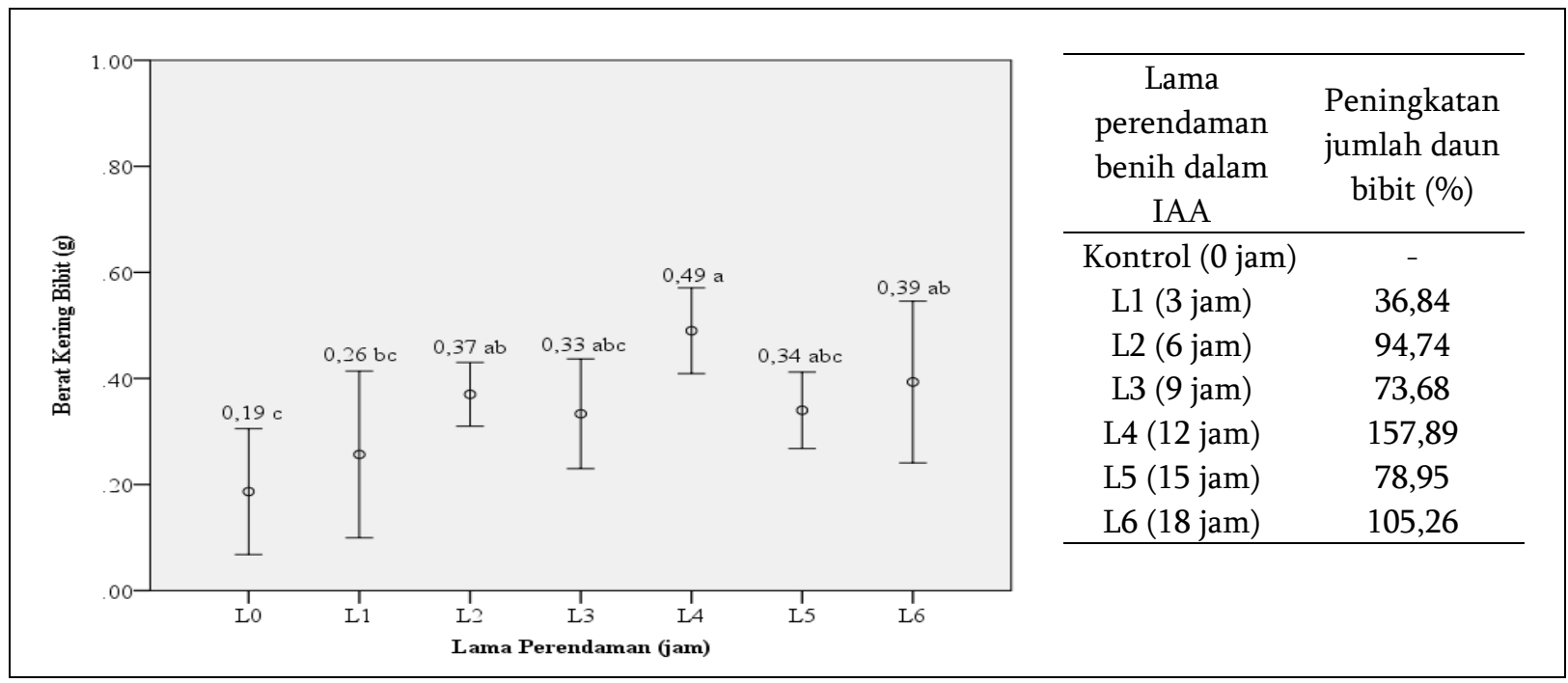

Gambar 5. Pengaruh lama perendaman benih dalam IAA terhadap berat kering bibit tanaman cabai merah varietas lokal Sumatera Utara dan persentase peningkatan berat kering bibit. Lama perendaman benih (L1=0 jam, L2= 3 jam, L2= 6 jam, L3=9 jam, L4= 12 jam, L5= 15 jam, L6= 18 jam. Lingkaran kecil pada grafik menandakan rataan berat kering bibit dan garis vertikal menunjukkan standar error. 
Pengaruh Beberapa Waktu Perendaman Benih Cabai terhadap Pertumbuhannya

Hasil penelitian ini menunjukkan bahwa lama perendaman benih dalam IAA dapat meningkatkan persentase daya kecambah, tinggi bibit, jumlah daun, berat basah, dan berat kering bibit cabai merah varietas lokal Sumatera Utara dengan peningkatan tertinggi pada setiap parameter pengataman tersebut terdapat pada lama perendaman benih 12 jam dengan nilai masingmasing sebesar $64,51 \% ; 49,04 \% ; 57,14 \% ; 117,50 \%$; dan 157,89\% dibandingkan kontrol (L0). Terjadi peningkatan daya kecambah, tinggi bibit, dan jumlah daun bibit cabai merah varietas lokal Sumatera Utara seiring dengan peningkatan lama perendaman sampai 12 jam dibandingkan kontrol kemudian mengalami penurunan sampai lama perendaman $18 \mathrm{jam}$. Hal ini disebabkan bahwa laju transport IAA tergolong linier sampai batas tertentu dan semakin lama waktu perendaman maka akan mengalami penurunan dikarenakan keberadaan karbondioksida melimpah. Hal ini sesuai dengan Gardner et al. (1991) menyatakan bahwa transpor auksin berlangsung dari ujung pucuk ke basal bersifat linier dan berlangsung sekitar $6 \mathrm{~mm} / \mathrm{jam}$, transpor auksin aktif di dalam floem (simplastik) dan laju transpor akan menurun dengan adanya karbondioksida $\mathrm{CO}_{2}$ atau tanpa $\mathrm{O}_{2}$. Ernawati dkk. (2017) melaporkan bahwa lama perendaman benih cabai merah kadaluarsa dengan air kelapa muda (ZPT auksin dan sitokinin) selama 6 jam signifikan meningkatkan kecepatan tumbuh, tinggi bibit, berat basah dan berat kering bibit cabai merah.

Selain itu lama perendaman benih akan mempengaruhi proses metabolisme dalam perkecambahan. Hal ini terlihat pada peningkatan daya kecambah, tinggi bibit, dan jumlah daun bibit cabai merah dari lama perendaman 0 sampai 12 jam kemudian mengalami hambatan sampai 18 jam perendaman. Tetapi berat basah dan kering (biomassa) bibit cabai merah mengalami peningkatan dari lama perendaman 0 sampai 6 jam kemudian biomassanya mengalami fluktuatif sampai 18 jam perendaman. Hal ini sejalan dengan penelitian Saini et al. (2017) menyatakan bahwa lama perendaman sangat penting dikarenakan perendaman dalam waktu yang terlalu singkat tidak dapat menyelesaikan proses metabolisme atau menghambat aktivitas enzim dalam meningkatkan perkecambahan atau kekuatan benih. Harris (1996) menyatakan bahwa lama perendaman yang terlalu lama dapat meningkatkan kemunculan radikula, namum lebih sensitif akan kehilangan air.

Pengaruh lama perendaman ZPT auksin terhadap benih tanaman lainnya juga sudah dilaporkan meningkatkan perkecambahan dan pertumbuhan bibit. Adnan dkk. (2017) melaporkan bahwa perlakuan lama perendaman dalam ZPT auksin signifikan meningkatkan daya kecambah, potensi tumbuh, indeks vigor, tinggi kecambah dan panjang akar benih semangka kadaluarsa dengan peningkatan tertinggi terdapat pada lama perendaman 4 jam. Alpriyan \& Karyawati (2018) melaporkan bahwa perlakuan waktu perendaman selama 40 menit dengan auksin signifikan meningkatkan luas daun bibit tebu bud chip. Supriyadi dkk. (2020) melaporkan bahwa lama perendaman benih lada dengan Rootone-F (ZPT auksin) signifikan meningkatkan panjang tanaman. Demikian pula dengan Saleem et al. (2014) yang melaporkan bahwa lama perendaman benih selama 12 jam dapat meningkatkan perkecambahan dan pertumbuhan bibit pada tanaman paria.

\section{SIMPULAN}

Lama perendaman benih dalam IAA signifikan meningkatkan persentase daya kecambah, tinggi bibit, jumlah daun, berat basah, dan berat kering bibit cabai merah varietas lokal Sumatera Utara. Peningkatan tertinggi terhadap parameter persentase daya kecambah, tinggi bibit, jumlah daun, berat basah, dan berat kering bibit ditemukan pada benih cabai yang direndam dalam IAA selama 12 jam dengan masing-masing sebesar $64,51 \%$; $49,04 \%$; $57,14 \% ; 117,50 \%$; dan $157,89 \%$ dibandingkan kontrol (tanpa perendaman).

\section{UCAPAN TERIMA KASIH}

Penulis mengucapkan terima kasih kepada Universitas Muhammadiyah Sumatera Utara yang telah mendukung dana penelitian ini dari Dana APB UMSU dengan nomor 08/KEP/II.3AU/UMSU/F/2020.

\section{DAFTAR PUSTAKA}

Adnan, A, BR Juanda, dan M Zaini. 2017. Pengaruh konsentrasi dan lama perendaman dalam ZPT auksin terhadap viabilitas benih semangka (Citurullus lunatus) kadaluarsa. Agrosamudra, Jurnal Penelitian. 4(1): 45-57. 
Alpriyan, D, dan AS Karyawati. 2018. Pengaruh konsentrasi dan lama perendaman hormon auksin pada bibit tebu (Saccharum officinarum L.) teknik bud chip. Jurnal Produksi Tanaman. 6(7): 1354-1362.

Dirjen Hortikultura. 2008. Luas panen, rata-rata hasil dan produksi tanaman hortikultura di Indonesia. Departemen Pertanian, Jakarta.

Ernawati, P Rahardjo, dan B Suroso. 2017. Respon benih cabai merah (Capsicum annuum L.) kadaluarsa pada lama perendaman air kelapa muda terhadap viabilitas, vigor dan pertumbuhan bibit. Agritrop: Jurnal IlmuIlmu Pertanian, 15(1): 71-83. https://doi.org/10.32528/agr.v15i1.794.

Gardner, FP, RB Pearce, and RL Mitchell. 1991. Physiology of crop plants. Diterjemahkan oleh Susilo dan Subiyanto. Universitas Indonesia Press, Jakarta.

Gundala, BT, T Kurniawan, dan Halimursyadah. 2018. Pengaruh konsentrasi auksin dalam hydropriming benih cabai yang berbeda tingkat kadaluarsa terhadap viabilitas benih. Jurnal Ilmiah Mahasiswa Pertanian. 3(4): 159166. https://doi.org/10.17969/jimfp.v3i4.9378.

Harris, D. 1996. The effects of manure, genotype, seed priming, depth and date of sowing on the emergence and early growth of Sorghum bicolor (L.) Moench in semi-arid Botswana. Soil and Tillage Research. 40(1-2): 73-88. https://doi.org/10.1016/S0167-1987(96)800079.

ISTA. 2010. International rules for seed testing: Edition 2010. The International Seed Testing Association. Bassersdorf. Switzerland

Kementerian Pertanian. 2015. Outlook cabai. Pusat Data dan Sistem Informasi Pertanian, Kementerian Pertanian, Jakarta. Online at: http://epublikasi.setjen.pertanian.go.id/epubli kasi/outlook/2015/Hortikultura/Outlook\%20 Cabai\%202015/files/assets/common/download s/Outlook\%20Cabai\%202015.pdf.
Saini, R, PK Rai, BM Bara, P Sahu, T Anjer, and R. Kumar. 2017. Effect of different seed priming treatments and its duration on seedling characters of Bitter gourd (Momordica charantia L.). Journal of Pharmacognosy and Phytochemistry. 6(5): 848-850.

Saleem, MS, M Sajid, Z Ahmed, S Ahmed, N Ahmed, and MSU Islam. 2014. Effect of seed soaking on seed germination and growth of bitter gourd cultivars. IOSR Journal of Agriculture and Veterinary Science. 6(6): 7-11.

Septiana, A, dan T Islami. 2018. Respon tiga varietas tanaman cabai besar (Capsicum annum L.) pada dua jenis pupuk organik. Jurnal Produksi Tanaman. 6(12): 3079-3085.

Setiawan, AB, S Purwanti, and Toekidjo. 2012. Pertumbuhan dan hasil benih lima varietas cabai merah (Capsicum annum L.) di dataran menengah. Vegetalika. 1(3): 1-11. https://doi.org/10.22146/veg.1345.

Soelaiman, V, dan A Ernawati. 2013. Pertumbuhan dan perkembangan cabai keriting (Capsicum annuum L.) secara in vitro pada beberapa konsentrasi BAP dan IAA. Buletin Agrohorti. $1(1)$ : 62-66. https://doi.org/10.29244/agrob.1.1.62-66.

Soetiarso, TA, Purwanto, dan A Hidayat. 1999. Identifikasi usahatani tumpanggilir bawang merah dan cabai merah guna menunjang pengendalian hama terpadu di Brebes. Jurnal Hortikultura. 8(4): 1312-1329.

Soetiarso, TA, W Setiawati, dan D. Musaddad. 2011. Keragaan pertumbuhan, kualitas buah, dan kelayakan finansial dua varietas cabai merah. Jurnal Hortikultura. 21(1): 77-88. http://dx.doi.org/10.21082/jhort.v21n1.2011.p 77-88.

Supriyadi, T, TS KD, E Suprapti, dan A Budiyono. 2020. Pengaruh konsentrasi dan lama perendaman stek lada (Piper nigrum) dalam larutan zat pengatur tumbuh (auksin). Jurnal Ilmiah Agrineca. 20(2): 158-169. https://doi.org/10.36728/afp.v20i2.1086. 